\title{
Rumination Time and Frequency of Goat Supplemented with Garlic Powder and Organic Chromium
}

\author{
Munasik*, Bahrun, Ihsan Yosinanda Sigar, Agustinah Setyaningrum and Caribu Hadi Prayitno \\ Faculty of Animal Science, Jenderal Soedirman University, Purwokerto, Indonesia \\ *Corresponding author email: munasik2011@gmail.com
}

\begin{abstract}
This research investigated the effect of supplementing garlic powder and organic micromineral $\mathrm{Cr}$ in feed on rumination time and frequency in Ettawah goat (PE). The research was conducted in Gunung Tugel Farm in Patikraja and the Laboratory of Feed Technology in Faculty of Animal Science, Universitas Jenderal Soedirman, Purwokerto, Central Java. This study used 18 male PE aged 1-1.5 years and weighed $18.62-22.69$ $\mathrm{kg}$. The feed consisted of $60 \%$ concentrate and $40 \%$ forage (field grass). Other materials included drinking water, $250 \mathrm{ppm}$ garlic powder (Allium sativum), $1.5 \mathrm{ppm}$ organic chromium mineral and eight CCTV camera. The observed parameters were rumination time and frequency. An in vivo experiment in a Completely Randomised Design (CRD) administered three treatments and six replicates, namely R0: control (basal feed); R1: basal feed $+250 \mathrm{ppm}$ garlic powder; and R2: basal feed $+250 \mathrm{ppm}$ garlic powder $+1.5 \mathrm{ppm}$ organic $\mathrm{Cr}$. The result demonstrated a significantly different effect of garlic powder and organic $\mathrm{Cr}$ micromineral supplement on rumination time across treatments, i.e. $404 \pm 19.6 ; 382 \pm 19.04$ and $351 \pm 13.87 \mathrm{~min} /$ day, respectively, or $379 \mathrm{~min} /$ day on average. Rumination frequency was not significantly different across RO, R1, and R2 namely $360 \pm 24.03 ; 359 \pm 30.13$ and $342 \pm 21.10$ times/day, respectively. Conclusively, garlic powder and organic $\mathrm{Cr}$ micromineral significantly affected rumination time, but not significantly affected rumination frequency of $\mathrm{PE}$ goat.
\end{abstract}

Keywords: garlic powder, Allium sativum, organic $\mathrm{Cr}$, feeding behaviour, rumination, Ettawah goat

Abstrak. Penelitian ini bertujuan untuk mengetahui mengetahui pengaruh penambahan tepung bawang putih dan mikromineral $\mathrm{Cr}$ organik dalam pakan terhadap lama dan frekuensi ruminasi kambing PE (Peranakan Etawa). Penelitian dilaksanakan di Gunung Tugel Farm, Patikraja, Banyumas dan Laboratorium IImu Bahan Makanan Ternak, Fakultas Peternakan, Universitas Jenderal Soedirman, Purwokerto, Jawa Tengah. Materi penelitian menggunakan 18 ekor kambing PE jantan dengan umur 1-1,5 tahun dan kisaran bobot 18,62 - 22,69 $\mathrm{kg}$. Pakan yang diberikan yaitu konsentrat sebanyak $60 \%$ dan hijauan berupa rumput lapang sebanyak $40 \%$, air minum, tepung bawang putih (Allium sativum) 250 ppm, mineral chromium organik 1,5 ppm, 8 buah kamera CCTV, 1 unit. Parameter yang diamati adalah lama waktu ruminasi dan frekuensi ruminasi. Metode penelitian yang digunakan adalah eksperimen secara in vivo dengan Rancangan Acak Lengkap (RAL) menggunakan 3 perlakuan dan 6 ulangan. Perlakuan terdiri atas R0 : kontrol (pakan basal) ; R1 : pakan basal +250 ppm tepung bawang putih ; R2 : pakan basal $+250 \mathrm{ppm}$ tepung bawang putih $+1,5 \mathrm{ppm} \mathrm{Cr}$ organik. Hasil penelitian menunjukkan bahwa penambahan tepung bawang putih dan $\mathrm{Cr}$ mikromineral organik terhadap waktu ruminasi berbeda nyata yaitu $404 \pm 19,6 ; 382 \pm 19,04$ dan $351 \pm 13,87$ menit/hari dengan rata-rata 379 menit/hari dan frekuensi ruminasi tidak berbeda nyata dengan jumah ruminasi perlakuan R0, R1 dan R2 : $360 \pm$ 24,03; $359 \pm 30,13$ dan $342 \pm 21,10$ kali/hari. Simpulan yang diperoleh adalah penambahan tepung bawang putih dan mikromineral $\mathrm{Cr}$ organik dalam ransum berpengaruh nyata terhadap lama ruminasi, namun tidak memberikan pengaruh nyata terhadap frekuensi ruminasi kambing PE.

Kata kunci : tepung bawang putih, Allium sativum, $\mathrm{Cr}$ organik, tingkah laku makan, ruminasi, kambing Peranakan Etawa

\section{Introduction}

Goat is a livestock commodity that significantly meets the demand of animal protein besides beef and poultry. PE goat is widely bred, but the development is hampered by insufficient nutrients and low energy intake, which lead to low daily weight gain. One of the solutions is improving feed quality to enhance cattle productivity. Feed is a crucial factor in breeding management, taking up $60-70 \%$ of production. Therefore, improving feed quality needs to consider the economic aspect and feed availability. Dry matter intake and requirement for goat is calculated from body 
weight the bigger the cattle, the higher the feed intake.

Supplementing garlic powder and $\mathrm{Cr}$ micromineral into ration is one alternative to improve feed quality and efficiency. Garlic contains allicin with antiprotozoal and antimethanogenic properties that could minimize the wasted feed energy in form of methane. Meanwhile, $\mathrm{Cr}$ micromineral improves cattle's body metabolism. Therefore, supplementing garlic powder enriched with allicin and $\mathrm{Cr}$ micromineral aims to inhibit protozoa growth and improve body metabolism. It was expected to prevent feed energy loss and optimize feed digestibility.

Rumination process starts when the cattle regurgitate the swallowed feed from the rumen in the form of bolus, then reswallow and passed it onto reticulum. The purpose of rumination is to reduce the size of feed particle, to improve feed area to ease microbe in degrading forage, and to stabilize ruminal $\mathrm{pH}$. Rumination time and frequency are affected by the type of feed, feed digestibility, feed composition, physiological status and cattle measurement. Observing the behaviour of ruminants is an indicator to measure feed quality and efficiency.

\section{Materials and Methods}

The observed parameters in this study were rumination time and frequency of male PE goat. This experimental study was conducted in a Completely Randomized Design with three treatments and eight replicates each. Feed concentrate plus garlic powder, and micromineral $\mathrm{Cr}$ supplement was rationed into four treatments, namely RO: control (basal feed), R1: basal feed +250 ppm garlic powder, and R2: basal feed +250 ppm garlic powder + 1.5 ppm organic Cr. A CCTV was used for $2 \times 24$ hour observation, and the manual observation kit included observatory sheet, a hand counter and a stopwatch. An analysis of variance in a Completely Randomized Design (CRD) investigated the treatment effects on rumination time and frequency. Any significant difference was further tested using Duncanttest. The goats were under treatment for 8 weeks, including 2-week adaptation, 2-week preliminary, and 4-week feeding trial and observing feeding behavior. The goats were placed in individual cages, measuring $1 \times 1.25$ meters. Feed was given $4 \%$ of body weight, 2 times a day (morning and evening).

The feed was made of $40 \%$ forage (field grass) and $60 \%$ concentrate consisted of $1 \%$ salt, $1 \%$ mineral mix, $1 \%$ soybean meal, $7 \%$ palm waste, $11.5 \%$ groats, $12.5 \%$ soybean husk, 15\% CGF (Corn Gluten Feed) and 48\% pollard.

\section{Result and Discussion}

\section{Dry Matter and Organic Intake}

The results showed that supplementing 250 ppm garlic powder in goat feed increased feed consumption (DMI or $\mathrm{OMI}$ ), but when compared with body weight there was a significant decrease. It demonstrated that garlic powder supplemented into goat feed increased feed efficiency although the combined garlic powder + organic $\mathrm{Cr}$ minerals produced nonsignificant effect. Also, garlic powder supplementation increased feed flow rates in the digestive tract and improved feed consumption. This condition was due to the enhanced digestive process of feed in the rumen (ruminal bacteria activity) and an improved feed utilization.

Table 1. Nutrient content

\begin{tabular}{lccccc}
\hline Feed & DM (\%) & CP (\%) & CF(\%) & Fat (\%) & TDN (\%) \\
\hline Concentrate & 88.7 & 18.24 & 11.54 & 7.48 & 39.79 \\
Forage & 34.31 & 7.05 & 32.42 & 0.38 & 26.53 \\
\hline
\end{tabular}


Table 2. Dry matter intake (DMI), organic matter intake (OMI) and rumination time

\begin{tabular}{|c|c|c|c|c|}
\hline Parameters & Ro & R 1 & R 2 & Mean \\
\hline \multicolumn{5}{|c|}{ 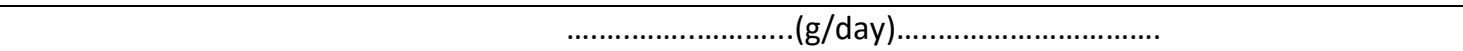 } \\
\hline Dry matter intake & 820.34 & 902.21 & 916.37 & 897.64 \\
\hline DMI /Body weight (\%) & 4.02 & 3.57 & 3.57 & 3.72 \\
\hline Organic matter intake & 495.83 & 560.87 & 566.87 & 541.19 \\
\hline DMO/Body weight (\%) & 2.77 & 2.51 & 2.46 & 2.58 \\
\hline Rumination time & \multicolumn{4}{|c|}{$\ldots(\min /$ day) } \\
\hline Day & 144 & 133 & 120 & 132.3 \\
\hline Night & 260 & 249 & 231 & 246.6 \\
\hline Total & $404 \pm 19.6^{\mathrm{a}}$ & $382 \pm 19.04^{b}$ & $351 \pm 13.87^{b}$ & 379 \\
\hline
\end{tabular}

\section{Rumination Time}

Rumination time is the duration for cattle to ruminate which depends on factors such as crude fibre content, feed type and feed shape. Rumination behavior is the process of discharging feed from the rumen to mouth (regurgitation) signified by the moving bolus from rumen to the throat. Measuring rumination time is one method to estimate feed efficiency and ruminant metabolism. The result of supplementing garlic powder and organic $\mathrm{Cr}$ mineral into feed is presented in Table 2 .

The result showed that daily rumination time in R0, R1 and R2 was $404 \pm 19.6,382 \pm$ 19.04 and $351 \pm 13.87$ minute per day, respectively, or 379 minutes per day on average. Supplementing garlic powder and organic $\mathrm{Cr}$ micromineral significantly affected rumination time $(P<0.05)$. Rumination time in this study was below 391 minutes of male Kacang goat weighed 8.77-13.87 kg and fed on high protein and high energy (Pembayun et al., 2013). Therefore, garlic powder and $\mathrm{Cr}$ micromineral supplemented into feed resulted in a better metabolism because the rumination frequency was shorter despite the higher body weight and higher feed intake.

Table 2 shows that cattle ruminated more frequently during the night than day, averagely 246 vs 132.3 minutes, respectively (46\% gap). This result confirmed Pembayun et al., (2013) that daylight rumination was shorter than the night, i.e. 165 and 226 minutes, respectively. Additionally, the extended rumination at night was because cattle generally feed during the day and ruminate at night (Rook, 2000). Day time rumination in this study was $29 \%$ shorter than Garut sheep with 100,6 minutes per 12 hours rumination (Oetami et al., 2015). This gap may due to different types of cattle in the study.

Garlic powder and organic $\mathrm{Cr}$ micromineral supplementation in Table 2 show significant effect $(P<0,05)$ on rumination time, where the shortest time was found in R2, i.e. $351 \pm 13,87$ minute per day, and the longest was $404 \pm 19,6$ minute per day. It indicated that goats offered with garlic powder and organic $\mathrm{Cr}$ micromineral supplementation in feed performed a more efficient body metabolism than those in control feed. Allicin in garlic could improve feed efficiency by inhibiting methanogenesis process, and organic $\mathrm{Cr}$ improves insulin activity which advances metabolism and progresses the efficiency of energy feed absorption. Prayitno et al. (2014) reported that Allicin in garlic is powerful to inhibit HMG-CoA reductase and methanogenesis process in the rumen. Supplementing organic $\mathrm{Cr}$ aimed to improve body metabolism. According to Adawiah et al. (2006), Cr micromineral contributes to protein metabolism, particularly incorporating amino acid to improve protein synthesis. Also, $\mathrm{Cr}$ physiological properties improves insulin 
activity a crucial hormone to increase glucose and amino acid uptake in cells (Suryadi et al., 2011).

Supplementing garlic powder and organic $\mathrm{Cr}$ in the ration was aimed to increase the efficiency of energy feed absorption and metabolism in cattle. Garlic powder functions as a defaunation agent and inhibits methanogenesis process in the rumen. Kongmun et al. (2010) reported that extract garlic powder for in vitro fermentation was effective against protozoa host and decreased total protozoa. Furthermore, supplementing basal feed with raw garlic or garlic oil was sufficient to reduce total protozoa in sheep (Anassori et al., 2011). Table 2 shows that supplementing garlic powder in feed resulted in a shorter rumination time compared to goat offered with control feed. Similarly, the tanninfortified feed was reported to perform $30 \mathrm{~g} / \mathrm{kg}$ DM defaunation in feed and reduce rumination time up to $5 \%$.

Supplementing 250 organic $\mathrm{Cr}$ in feed could improve body metabolism without obstructing cattle activity and reducing ruminal microbe population. Pechov and Pavlata (2007) informed that $\mathrm{Cr}$ supplementation in an in vitro animal tissue improved glucose oxidation, resulting in $\mathrm{CO}_{2}+\mathrm{H}_{2} \mathrm{O}$ formation, improving glycogenesis, and converting glucose to lipid which improved glucose utilization. Dallago et al. (2011) stated that supplementing 250-375 ppm chromium per day did not affect total ruminal protozoa (15-16 unit/mm3 ruminal fluid) and normal ruminal $\mathrm{pH}(6,49 \pm 0,28)$. However, supplementing 500 ppm chromium per day could significantly decrease total ruminal protozoa 21-day post-treatment into 69 unit/mm3 ruminal fluid.

The average one-day rumination time in Table 2 is 379 minutes per day or $48.3 \%$ lower than the previous studies. Male kacang goat fed on low-protein feed ruminated for 613.96 minutes a day (Riyanto et al., 2016), while goats fed with different levels of protein performed 391-minute rumination a day (Pembayun et al., 2013). The discrepancy may due to different feed types and quality and environmental factors. The contributing factors to cattle ruminating behavior may include, but not limited to, feed type and quality, environment and cattle age. The result in Table 2 shows shorter rumination time than that of Riyanto et al. (2016) and Pembayun et al. (2013); therefore, garlic powder supplementation could improve feed digestibility to perform shorter rumination. Yang et al. (2007) stated that garlic improves ruminant digestibility score - a higher digestibility resulted in higher efficiency.

Content in feed is a contributing factor to feed digestibility and ruminating behavior. The higher the crude fiber in feed, the lower feed digestibility; consequently, it extends rumination time. According to Oliveira et al. (2017) 3-month male Boer goats offered with $21 \%$ palm kernel biscuit in feed with high fibre and cellulose showed an extended rumination time by $13,8 \%$ from 339 to 393 minutes per day compared to basal feed. Galvao et al., (2019) reported that five-month male Boer goat offered with $14 \%$ tamarind waste supplement in high-fibre ration showed $12.6 \%$ extended rumination time compared to nonsupplemented feed.

\section{Rumination Frequency}

Cattle feeding behavior started from prehension, mastication (feed particle reduction), ensalivation (saliva secretion) before swallowing, and rumination. Measuring rumination frequency is a method to investigate feed efficiency and cattle metabolism (Pembayun et al., 2013). The result of garlic powder and mineral organic $\mathrm{Cr}$ supplementation in feed is presented in Table 3. The result showed that daily rumination frequency in PE goats offered with R0, R1 and R2 was $359 \pm 24.03,360 \pm 30.13$ and $342 \pm$ 21.10, respectively. Table 3 shows that supplementing garlic powder in ration did not 
Munasik et al./Animal Production. 21(2):87-92, 2019

Accredited by Kemenristek Dikti No 32a/E/KPT/2017. ISSN 1411-2027

Table 3. Dry matter intake feed and rumination frequency

\begin{tabular}{|c|c|c|c|c|}
\hline Parameter & R 0 & R 1 & R 2 & Average \\
\hline & \multicolumn{3}{|c|}{$\ldots$} & \\
\hline Dry matter intake & 820.34 & 902.21 & 916.37 & 879.64 \\
\hline Rumination frequency & & .........(time/ & ............ & \\
\hline Day time & 128 & 118 & 115 & 120.3 \\
\hline Nighttime & 225 & 238 & 226 & 229.6 \\
\hline Total & $359 \pm 24.03$ & $360 \pm 30.13$ & $342 \pm 21.10$ & 353.6 \\
\hline
\end{tabular}

significantly affect rumination frequency $(P>0.05)$. R2 showed the lowest frequency, i.e. $342 \pm 14.58$ times/day compared to R0 and R1 with a similar result, $354 \pm 17.24$ and $356, \pm$ 19.23 times/day, respectively. It was per garlic powder and organic $\mathrm{Cr}$ micromineral supplement that improved digestibility. According to Prayitno et al. (2014), supplementing garlic powder and organic mineral in concentrate could improve digestibility score. Also, improving feed digestibility would enhance the effectiveness of rumination activity. Pembayun et al., (2013) stated that Kacang goats fed with high crude protein and low crude fiber would ruminate in a shorter time than those fed with low crude protein and high crude fibre.

The highest feed intake $(1,028 \mathrm{~kg})$ and rumination frequency ( $360 \pm 30.13$ times/day) in this study were observed in R1. High rumination frequency in R1 was followed by high feed intake; therefore, high feed intake was positively correlated with rumination frequency. It was in line Oetami et al. (2015) that feed intake was related to rumination. Feed intake occurs due to hunger generated by stomach movement that induces a more frequent feeding and rumination.

Garlic powder supplementation in R1 (Table 3) resulted in similar rumination frequency to that in R0 despite higher feed intake in R1. Total rumination frequency was $360 \pm 30.13$ (R1) and $359 \pm 24.03$ (RO), while total feed intake was $1.028 \mathrm{~kg} /$ day (R1) and $0.997 \mathrm{~kg} /$ day (RO). It indicated that goat offered with garlic powder supplement in feed performed higher body metabolism than non-supplemented feed. RO and R1 shared similar rumination frequency, but feed intake in $\mathrm{R} 1$ was $4 \%$ higher than that in RO.

According to Hernawa and Ahmad (2003), allicin in garlic had hypoglycemic properties to lower blood glucose level. Furthermore, Oetami et al. (2015) stated that hypoglycemic condition could stimulate vagus nerve center in medulla oblongata to induce cholinergic that triggers stomach contraction, hence hunger. It stimulated higher feed intake and a more efficient metabolism in goats fed with garlic powder-fortified feed than the control group; therefore, rumination frequency was not significantly different despite higher feed intake.

Supplementing garlic powder and Organic $\mathrm{Cr}$ in feed was aimed to improve body metabolism. Garlic powder functions as methanogen inhibitor to minimize energy feed wasted in the form of methane. Table 3 shows that the lowest rumination frequency (342 \pm 21.10 times/day) was observed in R2 with garlic powder and organic $\mathrm{Cr}$ supplement. According to Taoma (2016), allicin supplementation in female sheep could lower methanogenesis by $47.07 \%$ and protozoa population by $15.19 \%$. Substituting hay with $10 \%$ garlic leaves into the ration could improve digestibility. Also, the chromium-fortified feed could improve amino acid and glucose absorption in the muscle (Amata, 2013), improve lipid synthesis in adipose tissue, and affect cholesterol and triglyceride metabolism. However, further investigation has not been conducted. 


\section{Conclusion}

Observation on ruminating behaviour to $\mathrm{PE}$ goat offered with garlic powder and organic chromium supplement in feed showed the fastest rumination time ( $351 \pm 13.87$ minute per day) and the lowest rumination frequency (342 \pm 21.10 times/day). Male PE goat ruminated for 379 minutes/day on average for 353.6 times/day.

\section{Acknowledgement}

The authors are grateful to Rector and Chief of LPPM UNSOED for the Applied Research grant No: P/793/UN23/14/PN/2019.

\section{References}

Adawiah T. S., T. Toto, M. Wasmen and Nahrowi. 2006. Respons Kualitas Susu pada Suplementasi Kacang Kedelai Sangrai and Sabun Kalsium serta Mineral Organik dalam Ransum Sapi Perah. JITV. 11: $28-287$.

Anassori E., N. B. Dalir, R. Pirmohammadi, A. S. Taghizadeh and M. Maham. 2011. Garlic: a potential alternative for monensin as a rumen modifier. Livestock Sci. $14:$ 276-87.

Amata I. A. 2013. Chromium in Livestock Nutrition: A Review. J. of Agri.Sci. 2 : 289 - 306.

Dallago B. S. L., C. M. McManus, D. F. Caldeira, A. Lopes. C. T. P. Franco, B. O. Borges, P. H. F. Teles, P. S. Correa and Louvandini. 2011. Performance and ruminal protozoa in lambs with chromium supplementation. Res. in Vet. Sci. 90 : 253-256.

Galvao J. M., T. M. Silva, W. P. Silva, P. R. S. Pimentel, A. M. Barbosa, T. V. C. Nascimento and A. G. V. O. Lima. 2019. Intake, digestibility, ingestive behavior and nitrogen balance of goats fed with diets containing residue from Tamarind fruit. Trop. Anim Health Prod.

Hernawan U. E and D. S. Ahmad. 2003. Senyawa Organosulfur Garlic (Allium sativum L.) and Aktivitas Biologinya. Biofarmasi. 66 : 65 - 76.

Kongmun, P., W. Mita, P. Pakdee and C. Navanukraw. 2011. Effect of coconut oil and garlic powder on in vitro fermentation using gas production technique. J.Livestock Sci.. 12 : 38 44.

Oetami, N., H. Dennie and C.B Dwi. 2015. Tingkah Laku Deglutisi, Regurgitasi, and Redeglutisi Serta Lama Rumination pada Domba Garut yang dikandangkan. Students e- Journal. 4(3):18-28.

Oliveira, R. L., G. G. P. Carvalho, M. S. L. Tosto, M. Santos, R. B. X. Ribeiro, T. M. Saliva and L. M. A. Rufino. 2017. Palm Kernel Cake Obtained from Biodiesel Production in Diets for Goats: Feeding Behavior and Physiological Parameters. Trop Animal Health Prod. 49 : 1401-1407.

Pembayun, I. H., A. Purnomoadi and S. Dartosukarno. 2013. Tingkah Laku Makan Kambing Kacang Yang Diberi Feed Dengan Level Protein-Energi Berbeda. Anim. Agric. J. 2 : 31-36.

Pechova, A. and L. Pavlata. 2007. Chromium as an essential nutrient: a review. Veterinarni Medicina. 52 : 1-18.

Prayitno. C. H., T. R. Sutardi and Suwarno., 2014. Supplementation effect of herbal and organic minerals in beef cattle feed on consumption, digestibility, efficiency and daily gain. J. Anim. Prod. 16: 88-94.

Riyanto, Agung, Dartosukarno, Sularno and Purnomoadi. 2016. Tingkah Laku Makan dan Rumination Kambing Kacang Yang Diberi Feed Dengan Sumber Protein Yang Berbeda. Thesis undergraduate.Fakultas Peternakan and pertanian. Universitas Diponegoro. Semarang.

Rook J. A. 2000. Principles of Foraging and Grazing Behaviour. Page 229 in Grass: its production and utilization. A. Hopkins, ed. Blackwell Science.

Suryadi, U., U. Santosa and U. H. Tanuwiria. 2011. Strategi Eliminasi Stres Transportasi pada Kambing Potong Menggunakan Kromium Organik. Unpad Press, Bandung.

Taoma, D. Chen, Y. Tu, N. Zhang, B. Si, K. Deng and Q. Diao. 2016. Effect of supplementation of allicin on methanogenesis and ruminal microbial flora in Dorper crossbred ewes. J. of Anim. Sci. and Bio. 1-7.

Yang, W. Z., C. Benchaar, B. N. Ametaj, A. V. Chaves, M. L. He and T. A. McAllister. 2007. Effects of garlic and juniper berry essential oils on ruminal fermentation and on the site and extent of digestion in lactating cows. J. Dairy Sci. 90: 5671 $-5681$. 